\title{
Antibody Prevalence to Human Enteric Coronavirus-like Particles and Indieations of Antigenic Difierences Between Particles from Different Areas
}

\author{
Brief Report
}

\author{
By \\ R. D. SchnagL ${ }^{1}$, Teresa Greco ${ }^{1}$, and F. MoreY ${ }^{2}$ \\ 1 Department of Microbiology, La Trobe University, \\ Bundoora, Victoria, Australia, \\ 2 Pathology Laboratory, Alice Springs Hospital, \\ Alice Springs, Northern Territory \\ With 1 Figure \\ Accepted May 31, 1985
}

\begin{abstract}
Summary
Antibody to human enteric coronavirus-like particles was detected in Australian Aborigines, but at lower levels or not at all in Europeans. There were indications of antigenic differences between particles from different areas. Support was provided for consideration of such particles as infectious agents.

There have been many reports on the finding in faeces of human enteric coronaviruses/coronavirus-like particles (CVLPs) from numerous different countries (reviewed by Mackavghton and Davies, 8), including Australia $(11,12)$. However, there have been reports from only two laboratories on their growth in organ or cell culture $(3,6)$, and this inability to be readily grown has severely hindered their characterization and general acceptance as infectious agents, particularly in the case of the so-called CVLPs.

Their association with diarrhoea in a causal role has been suggested by numerous workers $(3,4,5,6,7,13)$, but their excretion by many apparently healthy individuals in some instances $(1,7,9,11,12)$ has lead to some doubt about the role of CVLPs in enteric disease, particularly in adults. A recent report (5) has, however, suggested an antigenic similarity between what were identified as human enteric coronavirus strains and the human respiratory coronavirus $\mathrm{OC} 43$.
\end{abstract}


The finding of serum antibodies to this type of agent has been reported in a few specific disease related instances in neonates and infants $(4,5,13)$ but not in the case of adults (1). In this communication we report on the existence and prevalence of serum antibody to human enteric CVLPs in Central Australia and Melbourne, Australia, as a result of a small but more general survey than has previously been conducted. We also report on the indication of possible antigenic differences between CVLPs from different areas.

Sera were obtained from male and female Aborigines living within a $300 \mathrm{~km}$ radius of Alice Springs, Central Australia, who had been admitted to Alice Springs Hospital in May-June, 1984 for a variety of reasons. Patients 1, 2, 5 and 11 (Table 1) had been admitted for diarrhoea. Faecal specimens from six of these patients (see Table 1) had been examined up to 12 months prior to the serum being taken and all of these had been found to be excreting CVLPs. Sera were also obtained from age- and sexmatched Europeans admitted to Alice Springs Hospital during the same period, also for a variety of reasons but none for diarrhoea. Sera from Melbourne European infants and children were obtained from patients admitted to the Royal Children's Hospital, Melbourne for a variety of illnesses, including one case of diarrhoea, while sera from Melbourne adults were randomly collected. All were age- and sex-matched to the Central Australian sera. All sera were inactivated at $56^{\circ} \mathrm{C}$ for 30 minutes before use.

For purification CVLP containing faecal specimens (Fig. 1a) were first clarified by centrifugation at $1300 \times g$ for 20 minutes. After centrifugation of the supernatants at $100,000 \times g$ for 1 hour the resultant pellets were layered onto a $10-50$ per cent $(\mathrm{v} / \mathrm{v}$ ) angiografin (Schering $\mathrm{AG}$, Berlin, Germany) gradient in phosphate buffered saline and centrifuged at 75,000 $\times g$ for 6 hours. CVLP containing fractions from this gradient were further purified by centrifugation in a 30 per cent $(\mathrm{v} / \mathrm{v})$ glycerol/50 per cent $(\mathrm{w} / \mathrm{w})$ potassium tartrate continuous gradient at $150,000 \times g$ for 17 hours. All purification procedures were carried out in the cold and the above highly purified CVLPs (Fig. 1 b) were used for the preparation of hyperimmune serum and for immune electron microscopy. For the preparation of the antiserum Balb/c mice were given four weekly intraperitoneal injections of CVLPs purified from faecal specimens obtained from several young Central Australian Aboriginal children in 1983. The first CVLP preparation only was mixed with an equal volume of Freund's incomplete adjuvant before injection. Mice were bled one week after the final injection.

For antibody titration the decoration method (10) was used. A loopful of purified CVLPs was applied to an electron microscope grid and the excess removed after one minute. Before the grid had time to dry it was floated on $10 \mu \mathrm{l}$ of appropriately diluted serum and maintained in a humidi- 
fier at room temperature for 30 minutes. Excess fluid was then removed and the grid stained with saturated ammonium molybdate. The decoration titre was taken as the reciprocal of the highest dilution of serum at which antibody (decoration) was found to be attached (Fig. 1c) to at least one
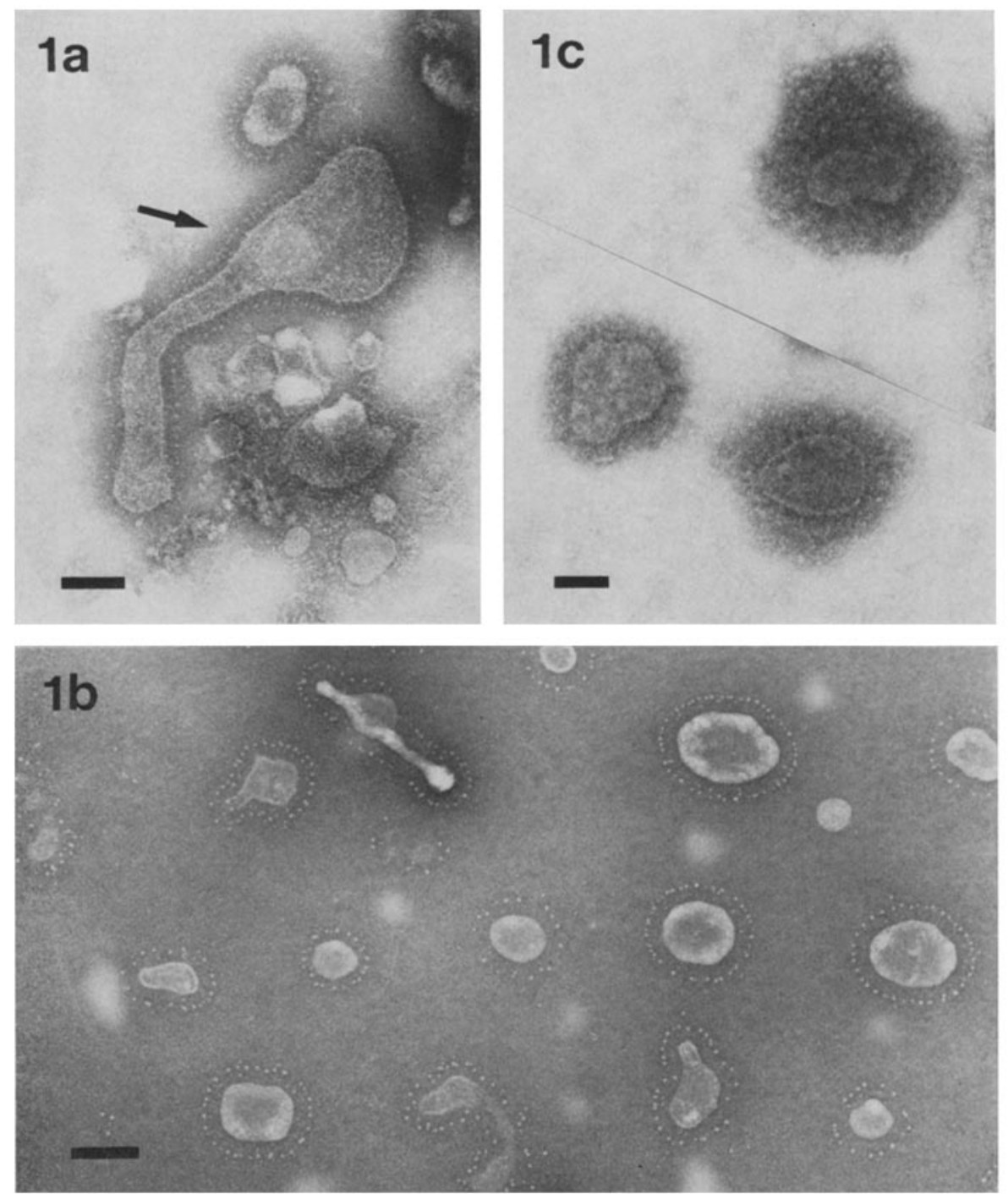

Fig. 1. $a$ CVLPs in a faecal extract from an Aboriginal child. Note the two pleomorphic particles surrounded by characteristically shaped surface projections or spikes. The large particle (arrow) may be an aberrant form. The bar represents $100 \mathrm{~nm}$. $b$ Highly purified preparation of CVLPs such as used for immune electron microscopy, from a glycerol/potassium tartrate gradient. The stalks of the CVLP spikes are not readily visible. The bar represents $200 \mathrm{~nm}$. $c$ Antibody (decoration) from the serum of an Aboriginal child covering the surface projections (spikes) of CVLPs. The bar represents 
Table 1. Serum antibody titres to OVLPs in Central Australian Aborigines admitted to Alice Springs Hospital

\begin{tabular}{rrrrrr}
\hline Patient & Age & $\begin{array}{l}\text { Decoration antibody } \\
\text { titre }\end{array}$ & Patient & Age & $\begin{array}{l}\text { Decoration } \\
\text { antibody } \\
\text { titre }\end{array}$ \\
\hline 1 & 5 months & 1000 & 11 & 4 years & 2000 \\
2 & $\mathbf{1 3}$ months & 1000 & 12 & 9 years & 1000 \\
$* 3$ & $\mathbf{1 3}$ months & 4000 & 13 & 20 years & 200 \\
$* 4$ & 14 months & 2000 & 14 & 22 years & 200 \\
5 & 14 months & 1000 & 15 & 26 years & 1000 \\
$* 6$ & 18 months & 2000 & 16 & 29 years & 100 \\
$* 7$ & 2 years & 4000 & 17 & 44 years & 100 \\
$* 8$ & 2 years & 500 & 18 & 55 years & 100 \\
9 & 3 years & 500 & 19 & 56 years & 1000 \\
$* 10$ & 4 years & 2000 & 20 & 68 years & 200 \\
\hline
\end{tabular}

* Patients found to be excreting CVLPs on one or more occasions prior to serum being taken. Faecal specimens from the other patients were not available for examination

Table 2. Serum antibody titres to CVLPs in Central Australian Europeans admitted to Alice Springs Hospital

\begin{tabular}{lcccll}
\hline Patient & Age & $\begin{array}{l}\text { Decoration antibody } \\
\text { titre }\end{array}$ & Pationt & Age & $\begin{array}{l}\text { Decoration } \\
\text { antibody } \\
\text { titre }\end{array}$ \\
\hline 1 & 5 months & 10 & 7 & 13 years & 50 \\
2 & 9 months & 10 & 8 & 20 years & 50 \\
3 & 18 months & 10 & 9 & 24 years & 50 \\
4 & 4 years & 10 & 10 & 35 years & 50 \\
5 & 5 years & 10 & 11 & 56 years & 10 \\
6 & 10 years & 100 & 12 & 67 years & 10 \\
\hline
\end{tabular}

of 100 observed particles. Clumping of CVLPs by antiserum was readily observed when this was tested for but this method was found not to be as reliable as decoration for routine titration of antiserum, partly because CVLPs were found to clump naturally on occasions. Titres of sera that were titrated by the clumping method, including the prepared hyperimmune serum, were always one hundred-fold lower than the corresponding decoration titres.

Decoration serum antibody titres to CVLPs in 20 Central Australian Aborigines are listed in Table 1. Titres ranged from 100 to 4000, with the younger children/infants generally having higher antibody levels and the adults generally lower levels. There was no difference between males and females in the prevalence of high and low titres. Titres to CVLPs in the 12 Central Australian Europeans tested were generally very much lower than those in the Aborigines (Table 2). They ranged from 10 to a maximum 
of 100 in one 10 year-old female. Of the 12 age- and sex-matched Melbourne Europeans' sera tested all had decoration titres to the CVLPs of two.

To test for any antigenic similarity or difference between Central Australian CVLPs and others from different areas of Australia and overseas, the homologous decoration titre of the prepared hyperimmune serum to the Central Australian particles was compared with titres obtained with this serum and purified CVLPs from faecal specimens from the following: a) a three year old European child with diarrhoea from Kalgoorlie, $1500 \mathrm{~km}$ south west of Alice Springs obtained in $1975, \mathrm{~b}$ ) a healthy 15 year old Aborigine from Fitzroy Crossing, $1000 \mathrm{~km}$ north west of Alice Springs obtained in 1977, c) a 16 year old Vietnamese immigrant to Australia, the specimen having been collected immediately on his arrival in Australia from transit camp in Indonesia in 1978, and d) a young adult with suspected tuberculosis on Kiribati (Pacific Ocean) obtained in 1979.

The homologous decoration titre of the antiserum against the Central Australian CVLPs used to raise it was determined to be 20,000 . The preinoculation titre of serum from the mice used to prepare this antiserum had been found to be two. Twenty thousand was also the titre obtained with the antiserum and each of several different purified preparations of Central Australian CVLPs from faecal specimens obtained in 1983 and 1984, and not used for the preparation of the hyperimmune serum. The decoration titre obtained with the antiserum and purified particles from Kalgoorlie (a) was 10,000 , but the titres obtained with CVLPs from the other areas were much lower. For those from Fitzroy Crossing (b) the titre was 2000, and for those from the Vietnamese immigrant (c) and from Kiribati (d) the decoration titres were 1000 , that is 10 - and 20 -fold lower than the homologous titre. Unfortunately sufficient CVLPs could not be obtained from the nonCentral Australian specimens to raise antisera and so the reverse titres could not be obtained. It would appear, however, that the Central Australian CVLPs may be antigenically similar to those from Kalgoorlie, but there are indications of some antigenic difference between the Central Australian CVLPs on the one hand and the Fitzroy Crossing, Vietnamese immigrant and Kiribati particles on the other.

Purified CVLPs were also tested for their ability to agglutinate human Group 0 , mouse, sheep and horse red blood cells at $4^{\circ}$ and $25^{\circ} \mathrm{C}$, but without success.

In Australia antibody levels appear to follow the observed excretion rates of CVLPs in the different populations that have been tested. In Central Australia up to 85 per cent of Aborigines were reported to have been excreting CVLPs, whereas only up to 18 per cent of Europeans were found to be excreting them (12). In this study serum antibody levels to CVLPs were generally found to be very much higher in the Aborigines than in the Central Australian Europeans. Further, the excretion rate of CVLPs in the 
Melbourne population has been found to be less than 1 per cent (11 and R. D. Schnagi, unpublished data), and correlating with this no definite evidence of antibody to CVIPs was found in the Melbourne sera tested. The decoration titres of two obtained were very possibly just a result of slightly cross-reacting antigens in conjunction with the high concentration of antibodies in the concentrated sera at a dilution of one in two.

These findings therefore tend to lend support to the contention that the CVLPs may in fact be infectious agents. They may play a role in the chronic diarrhoea prevalent amongst the Aborigines (12) or just be tolerated enteric passengers in other instances, but whether they are coronaviruses, or similar to the coronaviruses or even Breda virus (2) remains to be determined.

\section{Aeknowledgements}

We gratefully acknowledge the assistance of Dr. J. Erlich, the staff of the Pathology Laboratory, Alice Springs Hospital, Dr. R. F. Bishop, Dr. J. R. L. Forsyth, and the Community Health Service and State Health Laboratories of Western Australia in obtaining the various faecal specimens and sera. We also acknowledge the financial support of the National Health and Medical Research Council of Australia.

\section{Reierences}

1. Baker, S. J., Mathan, M., Matran, V. I., Jesudoss, S., Swaminathan, S. P.: Chronic enterocyte infection with coronavirus. One possible cause of the syndrome of tropical sprue? Digest. Dis. Sci. 27, 1039-1043 (1982).

2. Beards, G. M., Hall, C., Greien, J., Flewerx, T. H., Lamoulratte, F., Du PaSQUTER, P.: An enveloped virus in stools of children and adults with gastroenteritis that resembles the Breda virus of calves. Lancet $i, 1050-1052$ (1984).

3. Caur, E. O., EgGzestone, S. I.: Further studies on human enterio coronaviruses. Arch. Virol. 54, 107-117 (1977).

4. Chany, C., Moscovidr, O. L., Lebon, P., Rovsset, S.: Association of coronavirus infection with neonatal necrotizing enterocolitis. Pediatrics 69, 209-214 (1982).

5. Gerna, G., Passarant, N., Cereida, P. M., Battactia, M.: Antigenic relatedness of human enteric coronavirus strains to human coronavirus OC 43: A preliminary report. J. Inf. Dis. 150, 618-619 (1984).

6. LAPoRTe, J., Bobulesco, P.: Growth of human and canine enteric coronaviruses in a highly susceptible cell line - HRT-18. In; PoLland M. (ed.), Perspectives in Virology, Vol. XI, 189-193. New York: Alan R. Liss 1981.

7. MAAS, G., BAUmeister, H. G.: Coronavirus-like particles as aetiological agents of acute non-bacterial gastroenteritis in humans. In: Huluary, I. B., HENNEssen, W. (eds.), Int. Symp. on Enteric Inf, in Man and Animals: Standardization of Immunological Procedures, Dublin, Treland, 1982 (Develop, biol. Standard., Vol. 53), 319-324. Basel: Karger 1983.

8. Machatghton, M. R., Davies, H. A. Human enteric coronaviruses. Brief review. Arch. Virol. 70, 301-313 (1981).

9. Mathan, M., Mathan, V. T., Swaminathan, S. P., Yesudoss, S., Baker, S. J.: Plemorphic virus-like particles in human faeces. Lancet $i, 1068-1069$ (1975).

10. Mitne, R. G., Lutsoni, E.: Rapid immune electron microseopy of virus prepa- 
rations. In: Maramorosch, K., Koprowski, H. (eds.), Methods in Virology, Vol. VI, 265-281. New York: Academic Press 1976.

11. Somnagl, R. D., Honmes, I. H., Mackay-Scoldax, E. M.: Coronavirus-like particles in Aboriginals and non-Aboriginals in Western Australia. Med. J. Aust. 1, 307-309 (1978).

12. Schnagl, R. D., Morey, F., Holmes, I. H.: Rotavirus, coronavirus-like particles, bacteria and parasites in Central Australia. Med. J. Aust. 2, 115-118 (1979).

13. Vatcher, Y. E., R.ay, C. G., Mrnaich, L. L., Payne, C. M., Beck, D., Lowe, P.: Pleomorphic, enveloped, virus-like particles associated with gastrointestinal illness in neonates. J. Inf. Dis. 145, 27-36 (1982).

Authors' address: Dr. R. D. Schnagl, Department of Microbiology, La Trobe University, Bundoora, Vic., 3083, Australia.

Received April 17, 1985

Verleger: Springer-Verlag KG, Molkerbastei 5 , A-1010 Wien. - Merausgeber: Dr. F. A. Murphy, Division of Viral Diseases, Centers for Disease Control, Atlanta, GA 30333. U.S.A. - Redaktion: Molkerbastei 5, A-1010 Wien, Hersteller: R. Spies \& Co., Straußengasse 16, A-1050 Wien. - Verlagsort: Wien. - Herstellungsort: Wien. Printed in Austria. 